\title{
II. COPING WITH SPINAL CORD INJURY^
}

\author{
Colette Ray, B.A., Ph.D., and Julia West, B.A. \\ Department of Psychology, Brunel University, Uxbridge, Middlesex UB8 ${ }_{3} P H, U . K$.
}

Summary. Paraplegia creates social, sexual and emotional problems, and the impact of these was investigated in an interview study of 22 male and female paraplegics. Of particular concern was the way in which individuals were coping with the difficulties confronting them. People used a number of strategies for dealing with other people and their attitudes, and for readjusting sexually. In dealing with their own personal feelings about their disability, ways of coping were varied and included suppression, denial and repession, resignation and acceptance, positive thinking and independence and assertiveness. No specific recommendations can be made about ways of coping that will be most adaptive, since these will depend upon the individual and his or her circumstances. What is important for counselling, however, is to recognise the range of coping strategies that are available, and to be able to guide the individual toward those which effect the best match between their needs and the demands of the situation.

Key words: Paraplegia; Coping; Psychology; Spinal Cord Injury.

Throughout a lifetime each individual is confronted with a variety of stressors which may threaten their psychological and physical well-being but whose effects can be modified by the response adopted toward them. People acquire skills of mastery and adaptation during childhood and beyond (Murphy, I962; White, 1959), and are not helpless in the face of a crisis. They bring to the situation personal and social resources which will influence both objective outcomes and the emotional impact of these, and also ways of perceiving which will determine their interpretation of the situation and of their own role in relation to it. Responses that are directed at the reduction of stress or the resolution of a crisis, whether or not they are successful in this, are described as 'coping'. They are 'the things that people do to avoid being harmed by life strains' (Pearlin and Schooler, I978, p. 2).

Spinal cord injury threatens the individual's well-being at a number of levels. Apart from imposing physical and practical restrictions it is a social stigma, it has sexual implications and it requires a radical revision in the person's self-image. After injury he or she may pass through a number of phases, from shock to defensive retreat, to acknowledgement and to adaptation (Fink, 1967). Full emotional adjustment may never be achieved for the injured as a group (Bourestom and Howard, I965; Geis, I972; Hohmann, I966). However, such generalisations will mask differences that exist between individuals in the group (see Paper I). At a social level, while some people may report restrictions as a result of injury, many will find that they have as many friends as before and have no difficulty in meeting people. Similarly, while for some paraplegia will bring about a change for the worse in their self image, others will experience a positive change, associated with a new self-awareness and appreciation of life, and heightened sensitivity and compassion. The theme of this paper will be

$\star$ Part I of this paper was published in Paraplegia, Volume 22, No. 2. 
the viewpoints and strategies for coping that people with spinal cord injury bring to bear upon their situation, and which determine its emotional outcome. In the study cited above, 22 male and female paraplegics, aged between 20 and 40, were interviewed, and asked about their problems and coping in three domains:

I. Social relationships, including both initial meetings with others, and friendships.

2. Sexual performance and relationships.

3. Personal adjustment.

Paper I outlines the procedure, and a selection of the sample. The descriptions which follow are based upon the group's appraisals of the disability and its implications, and their accounts of the strategies employed to avoid or alleviate stress, as given in the interviews. Within the social and sexual domains, there were some common themes expressed by those interviewed, and these will be reported first. Each individual, however, will evolve a stance which represents their own style of adjustment to a personal dilemma, and the remainder of the paper will deal with these diverse coping orientations.

\section{Social relationships}

One of the major problems that the spinally cord injured have to cope with is the attitudes of other people, who impose upon them stereotypes which inappropriately define their capacities and attributes (Katz, I98 I ; Rubington and Weinberg, I973). The disabled are often regarded not just as physically incapacitated but as ineffective in all ways. People treat you as though you are mute or deaf, or mentally retarded:

'When I shop, people tend to think 'Is there something wrong with her mind, can she talk to me, is she funny, is she simple'?

'Often, at first, people will talk about you as if you're an object sitting there that can't talk and has no mentality, e.g. 'Do you think she wants some tea'? is pity:

A reaction that is similarly patronising and that can cause similar pain,

'I came out of a shop one day and a child came up to me and said 'Oh, I do feel sorry for you'. There I was, struggling with crutches and a shopping bag trying to get out of this door, and honestly I must have looked a pitiable sight. I was fuming and angry at the frustration, but the child could only see this peculiar body with crutches trying to perform this impossible physical feat. This child just expressed how I looked. I could have sat down and cried, for me'.

Pity can also take the form of practical efforts to help, and disability gives others a licence to interfere even where help has not been requested:

'Other people insist on doing things for you that you don't want or ever need'.

'When I go shopping, people are more helpful. I like to be independent. Sometimes they're overpowering'. 
There is, however, action that the disabled person can take to avoid being relegated to a passive and dependent role, and this is to be selfassertive, even at the risk of causing offence:

'When you first get out of hospital, after being flat on your back for months, it's like being a Io month old baby again. People fuss over you and treat you like a little kid. Sometimes you have to say, 'Look, if I want, I'll ask'. You have to be cruel to be kind ... One guy came up to me and started pushing me. I said 'What do you think you're doing?' And he said 'I'm helping you', and I said, 'You're not bloody helping me you're hindering me. Go help some lady with a pram'. He was a bit offended. So I sat there and I said, 'Look, ask first. If I want help, give it to me, or if I really want help I'll ask for it. Otherwise let me get on with it'.

'You've got to educate the other people. You have to make them feel at ease, young and old. Every time you meet someone, you have to put over to them, 'There's nothing wrong with me, you can speak to me face to face, and crack jokes - even about wheelchairs, it's alright'.

The process can be seen as much as one of educating others as of asserting oneself. It is an attitude which can be helpful not only where others are threatening one's independence but in any social situation. For example, when meeting people it is useful to remember that they might be ill at ease and to go out of your way to combat this. They have a problem in dealing with disability which the disabled person can help with, by giving them the right sort of cues so that they know how to behave:

'I'm aware that others don't know the level of my disability so I offer my hand first-I know some disabled people are unable to use their arms/hands and since I can, I make the first move when I meet people so as to put them at ease'.

In a sense the disabled person is at an advantage in this kind of interaction:

'I know how they act, plus I know how I act-they don't know how I act as a disabled person. They only know about themselves'.

By fostering this kind of perspective, and focusing upon the other's needs, the disabled person will not only be helping the other and smoothing the interaction in general but can reduce his or her own self consciousness in the situation.

People cope with their disability at a physical level by planning their movements carefully and a similar use of foresight and strategy can help manoeuvres also in the social world. You can 'size up' people before you approach them on the basis of what their reaction is likely to be, and alter your own self presentation to reduce the awkwardness of a first encounter. Many say that they have become more sensitive to other people's reactions since their disability and that they have become more extroverted in their behaviour. The latter is 'an act', a social skill that has been acquired, to cope with new demands, rather than a change in the underlying personality:

'It's difficult, because I don't think I'm naturally one of the outgoing people who 
take the initiative in a conversation anyway. But I found out that I had to because otherwise new people didn't know how to handle me and unless I took the initiative and broke the ice, and gave them some sort of introduction, they didn't know how to start'.

'Once I learned to do that it was a lot easier, but I still find it a strain to say 'Here we are again'. I've got to be outgoing all the time, otherwise I'm completely ignored or people are horrendously uncomfortable and that's silly'.

Friendship is something that has to be worked at, by the ablebodied as well as the disabled, but perhaps more so by the latter. You have to go out and make friends rather than wait for them to come to you. You have to be careful not to impose upon them by asking too much, either practically or emotionally:

'I think, if you can present the brave front all the time and reassure them you'll only use their friendship intermittently, they're quite happy. But if you ever show your despair or any signs of great demand that the State cannot provide, then you must get your family to do that because that's their responsibility'.

On the other hand, you must not shut them out of your life and make your friends feel that there are taboo areas which they cannot enter. Again, as with strangers, it can be a revelation to the disabled person when they recognise that they can help their friends rather than just vice versa:

'I found I was far more rehabilitated than my friends and relatives were. It seemed that they (friends) would never get over it at first. I had to help them'.

\section{Sexual relationships}

Spinal cord injury will affect sexual functioning, with the nature and degree of the effects depending upon the level and completeness of the lesion. There may be problems with finding a comfortable and satisfactory position for intercourse, with spasms or with incontinence, and (for men) with achieving and maintaining an erection. Physical sensations will also be affected. Relatively few people withdraw from sexual activity after injury. For some, especially those with a loving and understanding partner, there may be little problem:

'I've never been shy of sex and I love it. It all depends on how you feel about sex. Certainly this has changed but it's still very normal. We have a lot of fun. It's not affected intercourse; it's different, that's all'.

Most practical difficulties can be met with techniques which come from imagination, trial and error, and practice. It is true that sex can, under these circumstances, become an 'obstacle course', and can lose its attraction because of the complexities now involved:

'It's how you think of it, in what way you think of it, that's how it restricts you and then that's what puts other people off you. And then you don't want to and there's no point if you don't want to anyway'. 
On the other hand, with a spirit of compromise and, above all, a sense of humour, this barrier can be overcome:

'You have to learn to laugh as well, to have pleasure. It is the sense of humour which helps you to get out of all sorts of different situations which needn't culminate in sexual satisfaction at all. The whole thing sort of collapses in a heap of bodies because of laughter'.

As well as developing new techniques, the disabled person can focus upon those sensations and sources of pleasure which are still available. For example, the emotional fulfilment of the sexual act may be stressed rather than physical release, and there may be a greater feeling of involvement in one's partner's pleasure as opposed to the gratification of one's own needs.

However, there are implications of disability which are not coped with as easily. For many people, the greatest problem is the loss of confidence in their attractiveness as a partner and in their identity as a sexual being, as opposed to their ability to perform sexually:

'It's when I see other people, mainly attractive women, it makes me feel unattractive and it gets me. I think it's jealousy, a yearning inside me to be different'.

'I think girls in wheelchairs are trying to prove to everyone that they're as good as before and still catch a man on his feet. I think they feel like I do, that they're maybe not as good as a woman on her feet'.

'I feel like it (accident) has taken away my womanhood'.

They may have had an actual experience of rejection:

'My boyfriend I had at the time (of the accident), was all right while I was in bed, but as soon as I got up and got in a wheelchair, that's when he started changing. Seeing me and knowing what I was before, he just couldn't handle it and he just drifted away. Even though I saw him every day at work, even when he talked to me, it was as if our relationship never happened. We were so close and I really loved him; I still do now. He would never even speak to me again and I don't really know why to this day'.

These self doubts and feelings of inadequacy can be more difficult to overcome than specific problems of sexual performance per se.

\section{Personal adjustment}

After injury, people have to cope not only with the objective difficulties which result physically, socially and sexually, but also with their own feelings about their disability. They experience helplessness and frustration, regret for what has been lost and anxiety about the future. There are a number of different ways of coping with such feelings. Individuals differ not just in the degree of impact of the disability experienced but in the way in which they qualitatively view this impact and attempt to minimise it. These personal styles or orientations will be dealt with under the headings suppression, denial and repression, resignation and acceptance, positive thinking, and independence and assertiveness.

Suppression. The face that the paraplegic shows to the world does not 
always reflect his or her true feelings. Many people cultivate an appearance of not caring, of being able to cope, both to give themselves the courage to go on and also to hide their vulnerability from others:

'If you get embarrassed you have to remember that it doesn't hurt. If someone laughs at you, big deal. Get nonchalant. You have to act, give out a feeling of not caring; you have to act tough, but deep down you do care a lot. Some nights I come in and someone's said something that deep down hurts me, so I have a quick go at the weights and then forget it. I put it out of my mind then. A bit of physical exercise works it out of you. You work up a good sweat and have a bath. Then, O.K., right, forget it'.

It is an attitude that is encouraged in hospital, where you are encouraged to act positively, however you are feeling inside: to laugh and to joke when you feel like crying, and to be physically active and competitive when your instinct is to give up. In their social lives later, many people say that they are extroverted and dynamic as far as outer appearances are concerned, while using this as defence against showing their real feelings to anyone:

'I bottle up my feelings. I talk about it but only what $I$ want to talk about. I control it - I don't ever expose myself (feelings). I find I never let people know all about me. There's me as me, as an extrovert, but the real me is the shy, meditating me, and no one knows about this really'.

Denial and repression. There are ways of coping that are superficially similar to suppression but here the person is trying to refuse to acknowledge, or to put out of his or her own mind, the fact of the disability and its implications. They may focus on the present rather than the past or the future and not let themselves think too much about their feelings:

'I've got a knack now of not dwelling too long on what was'.

They may be reluctant to associate with other disabled people, or to be identified with the disability. They feel that they are the same person that they were before and that nothing has changed:

'When I associate with normal people I forget I'm in a wheelchair; people allow me to be myself. When you're in a group of other disabled people in wheelchairs you're drawn to the fact all the time; you're constantly reminded of it. And I don't want to think of it. I want to carry on my life like everybody else; do exactly the same things hopefully, but just be different in being in a wheelchair'.

Denial does not necessarily imply a distortion of reality. It can be just a bias in the way that the situation is evaluated (toward the positive rather than the negative), and toward maintaining the status quo rather than making adjustments in the light of changed circumstances.

'I'd prefer to be called a cripple, than a disabled-a disabled means you're old, and a cripple I can laugh at, so it can be dismissed. I'd rather be called crippled, that's something I can separate myself from, where disabled is you, and I don't like that'.

Resignation and acceptance. For some people adjustment to disability 
means a coming to terms with one's limitations. It means changing one's life style and limiting one's horizons, learning patience and not wanting to do more than one can:

'I've got my cross to bear and I must bear it; there's no choice. Eat humble pie. Make the best of what you've got left. I'm always trying, so I keep very physically fit. I play table-tennis, archery, go swimming three times a week. I go to work and I keep myself very busy. It's only a cover. I don't want to do anything I'm doing now. I don't want any of this, I've got life No. 2 at the moment, it's secondbest but it's all I've got. I really want to be average, normal, but I can't, so I settle for this'.

'You've got to accept to a point your limitations and get on with life, but then you're not the only person in the world with limitations-some have limitations with money, yours happens to be with a wheelchair; I think you have to meet your limitations'.

This kind of attitude can bring equanimity and peace of mind, but if the person is too passive and acquiescent it can foster feelings of helplessness and depression.

Positive thinking. This way of coping is very similar to the above but here it is the making the most of one's circumstances that is emphasised rather than their acceptance. In many different contexts people emphasise the importance of the effort that you yourself make in determining how well you adjust, personally, socially or sexually:

'If you're going to be a defeatist right from the world go, then you're finished'.

'The worse thing to do is to sit around and dwell on it (the injury) and a lot of people do, and they don't go out and they say and think, "Well, that's the end of it'. They make no effort'.

You have to think of life in positive terms, to 'count your blessings', and build confidence in your ability to cope.

'I certainly don't think it was the worst thing that ever happened to me, or ever could happen to me'.

'You must think positive all the time. I've been depressed but it's not lasting. I just grit and get up and get started again'.

Independence and assertiveness. People often argue that they are encouraged by the system of care provided, and by society in general, to be dependent and to rely upon others, but that this is a pressure which they themselves have resisted. You should not reject help where you need it but if you feel that you can cope on your own this enhances your self respect and confidence:

'If I wanted to, people could help me, but if you see a situation without people-then you've got to do it, and so you do it. This makes you feel stronger because you can, and do, do it'.

People with this attitude are rebelling, but rebelling in a constructive way, against the situation. This rebellion may begin within the hospital 
with a rejection of the kind of rehabilitation offered there and devising one's own form of therapy. It may then continue in the outside world where other people threaten your status as an independent person through their ignorance or their well-meaning, but unwelcome, attempts to help.

'The more people try to stop me from doing things the more I'm going to do them. I've always been that way. If I'm challenged, I do the opposite. But I think I'm more that way now than I was before. I'm much more assertive, more direct, maybe not as polite as I used to be, but then people don't treat me as a normal able-bodied person either. My feeling and my answer now is 'So what'?

\section{Implications}

Counselling patients may help them to explore different ways of coping with their disability and to select those that best meet their needs and resources. Some hospitals run programmes to prepare people with injuries for the problems they will face, with sex in particular, and to help them to overcome these (Chipouras, I979; Melnyk and Montgomery, I979; Steger and Brockway, I980), but it seems that patients in general do not receive adequate counselling as part of their routine care. There are a number of alternative sources of such support.

(a) Doctors. It is to the doctor that patients initially turn for information and reassurance (Pender, I974) but few doctors are able or willing to deal with people's emotional problems alongside their physical ones.

(b) Nurses. Nurses are often formally regarded as responsible for patients' emotional welfare, but patients may not recognise this aspect of the nursing role, and nurses may find themselves, in practice, dealing primarily with the patients' physical needs (Hockey, I976; Stockwell, I972). Moreover, nurses' training encourages them to focus upon patients' displays of emotion, and to meet these with surface reassurances rather than to tackle patients' underlying problems and sources of insecurity. In the context of sexual counselling, staff may rebuff questions and have negative attitudes toward the sexual needs of patients, and can feel that their own preparation for dealing with problems of this kind is inadequate (Conine et al., I980; Fitzpatrick, I974; Golub, 1975; Jacobsen, 1974).

(c) Specialist nurses. Specialist nurses are being used in an increasing number of fields to provide counselling support e.g. stomatherapists, mastectomy counsellors. In this role they can combine a training in, and experience of, counselling with a specialised knowledge of the medical situation in which counselling is required.

(d) Psychologists or other professional counsellors. If they are working within a hospital context, they can provide a service similar to that of the specialist nurse.

(e) Volunteers. People who have themselves been injured may be in a position to help the recently disabled. They can empathise with the latter's distress and give the reassurance that others have been through the same experience but have come through to a successful adjustment. However, some kind of screening process is advisable to eliminate unsuitable helpers. If they themselves have not properly adjusted to the situation they will be of little use as a model or guide. Also, a helper who has not solved his or her own problems may over-identify with the patient/client, and see the latter's problems in terms of his or her own. 
(f) Rehabilitation groups. These can be hospital-based, perhaps led by a multi-disciplinary team, or have a self-help format. In the latter case, even though not professionally led, some kind of leadership will normally evolve from within the membership.

No one form of coping can be claimed a priori to be superior to another. The effectiveness of each will depend upon the nature of the demands that are being met, the character of the person who is doing the coping and the optimal way of adjusting to disability, for any individual, will be one which achieves a good 'match' between these two sets of factors (Haan, I977). Any of the responses described in this paper could be adaptive, if the setting is appropriate, and maladaptive if employed in an extreme and overgeneralised fashion. For example, anger is quite a common early reaction to injury (Vincent, I975; Wittkower et al., I954). It can promote independence and deflect the attempts of well meaning others to dominate and dictate in one's life (Kerr and Thompson, I972). However, it is less satisfactory as a response if it leads to bitterness and resentment, or if it results in a 'pseudo-independence', with the person rejecting help, when this would be appropriate, and adopting unrealistic goals (Siller, I969). At this extreme, assertiveness becomes an obstinate refusal to face facts, and this can result in repeated frustrations leading to despair. Similarly, denial can be adaptive to the extent that it shields the person from the emotional implications of facts that cannot be changed, but maladaptive where it prevents him or her from making adjustments which would be possible given a full acknowledgement of the situation. Most people can be expected to react with denial at some stage but patients who continue with this response into the rehabilitation period may be vulnerable to severe depression at a later date (Roberts, I972; Stern and Slattery, I975; Vincent, I975). Two other ways of coping that are mentioned in the literature, and that are generally regarded as more adaptive than either denial or anger, are 'control' and 'acceptance'. In the former case, the individual identifies problems and is set to overcome these, but without aggression and within the limits of what is possible. In the case of acceptance the emphasis is on adjusting within one's self to changed circumstances, coming to terms with things as they are rather than trying to change them. It has been argued that it is acceptance that has been given the greater emphasis by psychologists and other health workers as the form of adjustment, thus subtly introducing a value bias into the analysis. Cross (I98I) and Finkelstein (I980) both claim that the notion of acceptance locates the problem within the person rather than in the physical and social barriers created by society, with the implication that the individual should submit to these constraints. Adjustment to disability could, it is argued, equally well be construed as a struggle against discrimination and for independent action. There are, then, no firm rules or recommendations, but a number of different pathways to adaptation.

\section{Acknowledgement}

The project was initiated and funded by the Society for the Sexual and Personal Relationships of the Disabled.

\section{RÉSUMÉ}

La paraplégie crée des problèmes sociaux, sexuels et émotionnels, et l'impact de ceux-ci a 
été examiné dans une étude-interview de vingt-deux(22) paraplégiques mâles et femelles. Ce dont il s'agissait en particulier était la façon dont les individus venaient à bout des difficultés qui les confrontaient. On employait plusieurs stratégies pour faire face aux autres et à leurs attitudes, et pour se réadapter sexuellement. En faisant face à leurs propres sentiments personnels au sujet de leur incapacité, ils avaient recours à des façons variées d'en venir à bout, y compris la suppression, le déni et la répression, la résignation et l'acceptation, la pensée positive et enfin l'indépendance et l'outrecuidance. On ne peut pas faire des recommandations spécifiques quant aux façons de se débrouiller qui seront les plus susceptibles d'adaptation, puisque celles-ci dépendront de l'individu(e) et de ses circonstances. Ce qui est important pour ceux qui les conseillent, cependant, c'est de reconnaitre la gamme de stratégies pour faire face qui est disponible et de savoir guider l'individu vers celles qui réalisent la meilleure correspondence entre ses besoins et les exigences de la situation.

\section{ZUSAMMENFASSUNG}

Die Paraplegie schafft soziale, geschlechtliche und emotionale Probleme, und der Aufschlag von diesen ist in einem Interview-Studium von zweiundzwanzig (22) männlichen und weiblichen Paraplegischen untersucht worden. Von besonderer Interesse war die Weise, worauf Einzelwesen sich mit den ihnen gegenüberstehenden Schwierigkeiten massen. Man wendete eine Reihe von Strategien an, um mit anderen Leuten und ihren Haltungen fertig zu werden, und um sich geschlechtlich wiederherzustellen. Was die Behandlung ihrer eigenen, persönlichen Gefühle über ihre Unfähigkeit betrifft, waren die Behandlungsweisen verschieden, und diese schlugen Unterdrückung, Verneinung und Verdrängung, Resignation und Annahme, positives Denken, und Unabhängigkeit und Ausdrücklichkeit ein. Keine spezifischen Empfehlungen können über die Behandlungsweisen gemacht werden, die sich am besten anpassen werden, denn diese sind vom Einzelwesen und seinen Umständen abhängig. Was aber für die Beratung wichtig ist, ist die Auswahl der zur Verfügung stehenden Behandlungsstrategien anzuerkennen, und das Einzelwesen zu denen führen zu können, die die beste Entsprechung zwischen ihren Bedürfnissen und den Lagebedarfen verwirklichen.

\section{REFERENCES}

Bourestom, N. C. \& HowARD, M. T. (I965). Personality characteristics of three disability groups. Archives of Physical Medicine, 40, 626-632.

Chipouras, S. (1979). Ten sexuality programmes for spinal cord injured persons. Sexuality and Disability, 2, 301-302.

Conine, T. A., Christie, G. M., Hammond, G. K. \& Smith-Mintou, M. F. (i980). Sexual rehabilitation of the handicapped: the roles and attitudes of health professionals. Fournal of Allied Health, 9, 260-267.

Cross, M. J. (I98I). The psychology of physical disability-helpful or harmful. Bulletin of the British Psychological Society, 34, 456-458.

Fink, S. L. (1967). Crisis and motivation: a theoretical model. Archives of Physical Medicine and Rehabilitation, Nov., 592-597.

FinkelsteIn, V. (1980). Attitudes and disabled people. World Rehabilitation Fund, No. 5, New York.

FitzPatrICK, W. F. (1974). Sexual function in the paraplegic patient. Archives of Physical Medicine and Rehabilitation, 55, $22 \mathrm{I}-227$.

GeIs, H. (1972). The problem of personal worth in the physically disabled patient. Rehabilitation Literature, 33, 34-39.

GoluB, I. S. (1975). When your patient's problem involves sex. $R N$., 38, 27-3I.

HaAn, N. (1977). Coping and Defending: Processes of Self-Environment Organisation. Academic Press, New York.

Hockey, L. (1976). Women in Nursing: a Descriptive Study. Hodder and Stoughton, Edinburgh.

HohmanN, G. W. (1966). Some effects of spinal cord lesions on experienced emotional feelings. Psychophysiology, 3, I43-156.

JACOBSON, L. (I 974). Illness and human sexuality. Nursing Outlook, 22, 50-53.

KATZ, I. (I98I). Stigma: a social psychological analysis. Lawrence Gilbaum, Hillsdale, New Fersey. 
Melnyk, R. \& Montgomery, R. (1979). Attitude changes following a sexual counselling program for spinal cord injured persons. Archives of Physical Medicine and Rehabilitation, 6o, 60 I-606.

Murphy, L. B. (1962). The widening world of childhood: paths toward mastery. Basic Books, New York.

Pearlin, L. I. \& Schooler, C. (1978). The structure of coping-Fournal of Health and Social Behaviour, 19, 2-21.

Roberts, A. H. (1972). Spinal cord injury-some psychological considerations. Minnesota Medicine, 55, I I I 5-I I I 7 .

Rubington, E. \& Weinberg, M. S. (1973). Deviance: the interactionist perspective. MacMillan, New York.

Siller, J. (1969). Psychological situation of the disabled with spinal cord injuries. Rehabilitation Literature, 30, 270-296.

Steger, J. C. \& Brockway, J. A. (I980). Sexual enhancement in spinal cord injured patients: behavioural group treatment. Sexuality and Disability, 3, 84-95.

Stern, P. H. \& Slattery, K. (I975). Spinal cord injury rehabilitation. New York State Fournal of Medicine, 75, 1029-1034.

Stockwell, F. (1972). The unpopular patient. Royal College of Nursing, London.

VinCEnT, P. J. (I975). Treatment of patients with spinal cord injuries. Canadian Nurse, 7I, 26-30.

White, R. W. (I959). Motivation reconsidered: the concept of competence. Psychological Review, 66, 296-333.

Wittkower, E. O., Gingras, G., Mergler, L., Wigdov, B. \& Lepine, A. (I954). A combined psychosocial study of spinal cord lesions. Canadian Medical Association fournal, 71, I09-I I5. 